\title{
VOLUNTARY BREATHHOLDING. I. PULMONARY GAS EXCHANGE DURING BREATHHOLDING ${ }^{*}$
}

\author{
By CHARLES D. STEVENS, EUGENE B. FERRIS, JOSEPH P. WEBB, \\ GEORGE L. ENGEL, AND MYRTLE LOGAN \\ (From the Departments of Internal Medicine and Psychiatry, University of Cincinnati, \\ College of Medicine)
}

(Received for publication April 22, 1946)

\section{INTRODUCTION}

When a subject is totally immersed in water while holding his breath, a loss of buoyancy occurs. This phenomenon can be demonstrated by resting the subject on 1 pan of a balance, the loss of buoyancy being reflected as a gain in weight on the balance. This gain in weight (or loss of buoyancy) was first observed by us while determining body density by an underwater weighing method (1). This gain in weight amounts to 200 to 500 grams per minute, depending on the size of the subject, and is due to a decrease in the volume of gas in the lungs during breathholding.

This report presents data describing this phenomenon and indicating its significance with respect to pulmonary gas exchange during breathholding.

\section{METHODS}

The apparatus for underwater weighing consists of a metal rectangular tub 7 feet by $2 \frac{1}{2}$ feet by 2 feet. Suspended in this tub is a pan on which a person can lie. The pan is suspended on a balance with an index scale of 500 grams graduated to 1 gram, and with a capacity of $5 \mathrm{kgm}$. A vertical tub is also used to advantage for some purposes, but data in this report are from experiments in the horizontal tub, in which pressure on the lungs and abdomen is similar, and amounts to only a few inches of water pressure. The subject is first tested under water so that the pan is properly balanced longitudinally and laterally, and sufficient counter weights are added so that the total weight is about $2 \mathrm{kgm}$. greater than that of the water displaced. The subject, after taking a deep breath, submerges and rests quietly on the pan while consecutive weighings are recorded as long as he can hold his breath. In experiments reported here, the usual preparation for breathholding was for the subject to expire maximally, and then inspire maximally,

\footnotetext{
1 The work described in this paper was done under a contract, recommended by the Committee on Medical Research, between the Office of Scientific Research and Development and the University of Cincinnati.
}

after breathing room air, commercial oxygen (approximately 100 per cent) or 10 per cent oxygen-90 per cent nitrogen for 3 to 5 minutes.

In order to learn more concerning $\mathrm{CO}_{2}$ and oxygen exchange during breathholding, studies of arterial blood gases and $\mathrm{pH}$, and of urinary excretion of $\mathrm{CO}_{2}$ were carried out during breathholding. The lung volume changes were verified by measuring the vital capacity (volume of maximal expiration) in routine fashion, and comparing it with the volume of maximal expiration at the end of periods of breathholding.

\section{RESULTS}

1. Underwater weight change during breathholding. In 60 underwater weighing experiments in which the subjects inhaled 100 per cent oxygen, there was, during breathholding, a consistent steady gain in weight of the range of 200 to 500 grams per minute in each subject, the magnitude varying chiefly with the size of the subjects.

In each of a few subjects, a comparison was made of the underwater weight change following inhalation of 100 per cent oxygen, of room air, and of 10 per cent oxygen. Because of the short period of breathholding which obtains with 10 per cent oxygen, difficulty is encountered in stabilizing the subject on the balance, so that swinging of the balance prevents accurate weighing. In a few instances, accurate weights were obtained with 10 per cent oxygen. A typical example of underwater weight change with each gas mixture is presented in Figure 1.

After breathing 100 per cent oxygen, the change in weight proceeds at a nearly constant rate as long as the subjects can hold their breath, that is, up to 5 to 6 minutes. After breathing ambient air, the change in weight also proceeds at a constant rate, but more slowly than following 100 per cent oxygen. The comparison of rates after 100 per cent oxygen, and after air, is presented in Table I. After breathing 10 per cent oxygen, the weight changes at a comparatively 


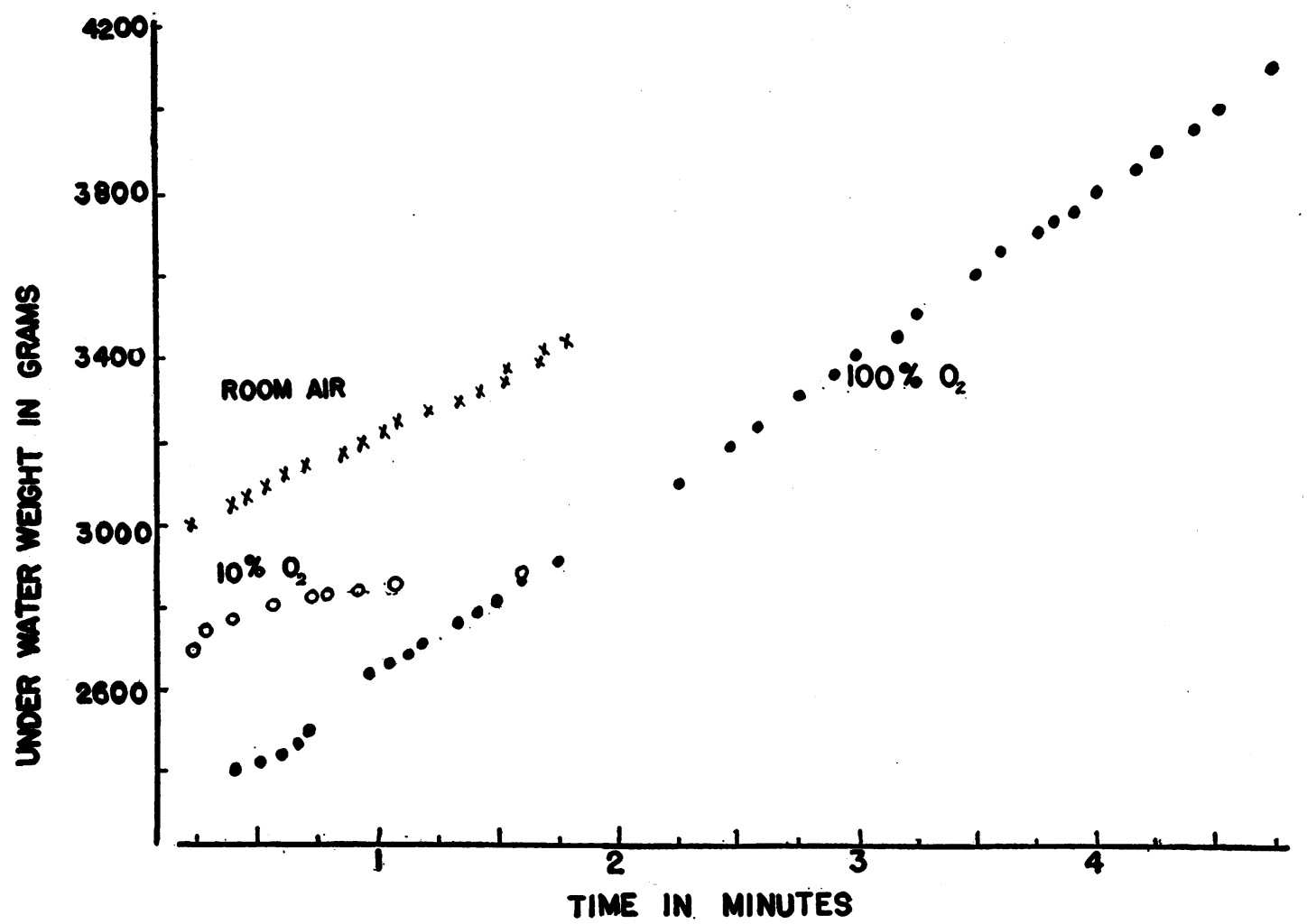

Fig. 1. An Example of the Changes in Underwater Weight

These studies made during periods of breathholding immediately following the breathing of air, 100 per cent oxygen, and a 10 per cent oxygen-90 per cent nitrogen gas mixture.

slow rate. These differences in weight gain will be discussed subsequently.

During the underwater weighing, there is no obvious loss of body gas externally, and no apparent reason to assume significant change of gas volume in the intestinal tract. Likewise, the depth of the body underwater is constant, so that changes in the volume of body gas due to variations in external pressure are insignificant. The only way to account for the change in body weight is to assume that the volume of gas in the lungs is decreasing.

2. Changes in vital capacity (maximum expiratory volume) during breathholding. In order to be certain that the above-mentioned phenomenon results from a decrease in the volume of lung gas, and not from an artefact inherent in the underwater weighing, maximum expiratory volume was measured after varying periods of breathholding. The subjects were seated and the vital capacity (maximum expiratory volume) measured after exhaling and then inhaling maxi- mally. Following adequate training, the subject after inhaling maximally, held his breath for as long as desired and then exhaled maximally into a spirometer. The procedure was carried out with 100 per cent oxygen. Sampling times were arranged to distribute in randomized fashion the variations due to training, fatigue, etc.

An example of the results is presented in Figure 2. The vital capacity decreases as the breath is held, and the rate of change is of the same order of magnitude as that occurring under water. This indicates clearly that the observed loss of weight during underwater breathholding is due to loss of gas from the lungs.

3. The relation of the underwater weight gain to the total oxygen consumption. The rate of oxygen consumption was determined in 3 subjects with a Benedict-Roth metabolism apparatus during inhalation of 100 per cent oxygen. This procedure was either followed or preceded by an underwater weighing following a period of 100 per cent oxygen breathing. The results are pre- 
TABLE I

Comparison in the rate of change in underwater weight during breathholding after breathing: $A$, room air, and $B, 100$ percent oxygen Weight Changes

\begin{tabular}{|c|c|c|c|c|}
\hline \multirow[b]{2}{*}{ Subject } & \multicolumn{2}{|c|}{$\mathbf{A}$} & \multicolumn{2}{|c|}{ B } \\
\hline & Run no. & $\begin{array}{c}\text { After } \\
\text { breathing } \\
\text { air }\end{array}$ & Run no. & $\begin{array}{c}\text { After } \\
\text { breathing } \\
100 \text { per } \\
\text { cent oxygen }\end{array}$ \\
\hline J.K. & $\begin{array}{l}1 \\
2 \\
3\end{array}$ & $\begin{array}{c}\text { grams per } \\
\text { min. } \\
333 \\
320 \\
285\end{array}$ & $\begin{array}{l}4 \\
5\end{array}$ & $\begin{array}{c}\text { grams per } \\
\text { min. } \\
365 \\
355\end{array}$ \\
\hline E.B.F. & $\begin{array}{r}8 \\
11\end{array}$ & $\begin{array}{l}240 \\
340\end{array}$ & $\begin{array}{r}9 \\
10\end{array}$ & $\begin{array}{l}330 \\
340\end{array}$ \\
\hline C.D.S. & $\begin{array}{l}1 \\
2 \\
3\end{array}$ & $\begin{array}{l}275 \\
280 \\
275\end{array}$ & $\begin{array}{r}9 \\
15\end{array}$ & $\begin{array}{l}410 \\
295\end{array}$ \\
\hline C.G. & $\begin{array}{l}2 \\
4 \\
8\end{array}$ & $\begin{array}{l}250 \\
285 \\
275\end{array}$ & $\begin{array}{r}3 \\
6 \\
10\end{array}$ & $\begin{array}{l}445 \\
404 \\
380\end{array}$ \\
\hline $\begin{array}{l}\text { I.G. } \\
\text { (first series) }\end{array}$ & $\begin{array}{l}1 \\
3 \\
9\end{array}$ & $\begin{array}{l}280 \\
300 \\
235\end{array}$ & $\begin{array}{l}4 \\
5 \\
8\end{array}$ & $\begin{array}{l}370 \\
340 \\
330\end{array}$ \\
\hline $\begin{array}{l}\text { I.G. } \\
\text { (second series) }\end{array}$ & $\begin{array}{r}1 \\
3 \\
6 \\
8 \\
9 \\
12\end{array}$ & $\begin{array}{l}320 \\
320 \\
325 \\
300 \\
305 \\
275\end{array}$ & $\begin{array}{r}2 \\
4 \\
5 \\
7 \\
10 \\
11\end{array}$ & $\begin{array}{l}390 \\
425 \\
405 \\
395 \\
320 \\
335\end{array}$ \\
\hline Average & & 291 & & 369 \\
\hline
\end{tabular}

sented in Table II. The rate of change in gas volume under water was significantly slower than the rate of oxygen uptake as measured by the metabolism apparatus, but the difference was small. If the decrease in weight we observe is due to loss of oxygen from the lungs, it is counteracted by only small accumulations of gaseous $\mathrm{CO}_{2}$ in the lungs, as, indeed, Hill and Flack found to be the case (2).

4. Loss of carbon dioxide in the urine during breathholding. It is clear that during breathholding only small amounts of $\mathrm{CO}_{2}$ enter the lungs as a gas. In order to discover whether $\mathrm{CO}_{2}$ in significant amounts might escape from the body dissolved in urine, a patient was subjected to breathholding with ureteral catheters in place, the urine being collected at 30-second intervals. By means of an intravenous dye test, it was determined that no urine leaked into the bladder around the catheters. The results are shown in Figure 3. Although some lag occurs between the breathholding and the urinary changes, there is a minor increase in the volume of urine and of $\mathrm{CO}_{2}$ excreted following breathholding. Taking this lag into account, the maximum loss of $\mathrm{CO}_{2}$ in the urine possible for the period of breathholding is only $1.2 \mathrm{ml}$. per minute in the first trial, and $2.0 \mathrm{ml}$. per minute in the second trial. If total $\mathrm{CO}_{2}$ production is assumed to be approximately $250 \mathrm{ml}$. per minute, the loss of $\mathrm{CO}_{2}$ in the urine accounts for less than 1 per cent of the total.

5. Changes in oxygen content, carbon dioxide content and $\mathrm{pH}$ of arterial blood during breathholding. An example of the changes in the gas content of arterial blood during breathholding after maximal inhalation of room air, of 100 per cent oxygen and of ambient air at 16,000 feet, is shown in Figure 4 (also see Voluntary Breathholding, Part III). The initial values are from blood obtained during normal respiration just prior to the breathholding procedure. The immediate sharp fall in $\mathrm{CO}_{2}$ illustrates the extent to which the single preliminary exhalation and maximum inhalation ventilate the alveoli. If one assumes that the $\mathrm{CO}_{2}$ content of venous blood rises as does that of arterial blood, there is an accumulation of $\mathrm{CO}_{2}$ in the blood of, roughly, 2 volumes per cent per minute, or $100 \mathrm{ml}$. per minute for a circulating blood volume of 5 liters.

The tension of $\mathrm{CO}_{2}\left(\mathrm{pCO}_{2}\right)$ in the arterial blood can be assumed to approximate that in the alveoli. From the increase in alveolar $\mathrm{pCO}_{2}$ (cal-

TABLE II

Comparison of the rate of oxygen consumption with the rate of change in gas volume during underwater weighing

\begin{tabular}{|c|c|c|c|c|}
\hline \multirow[b]{2}{*}{ Subject } & $\mathbf{A}$ & B & \multirow[b]{2}{*}{$\begin{array}{l}\text { Difference } \\
\text { between } \\
\mathrm{A} \text { and } \mathrm{B}\end{array}$} & \multirow[b]{2}{*}{ Remarks } \\
\hline & $\begin{array}{l}\text { Oxygen up- } \\
\text { take by the } \\
\text { Benedict- } \\
\text { Roth } \\
\text { Apparatus }\end{array}$ & $\begin{array}{c}\text { Gas volume } \\
\text { change by } \\
\text { underwater } \\
\text { weighing }\end{array}$ & & \\
\hline C. G. & $\begin{array}{c}\text { ml. at } N . T . P . \\
\text { per min. } \\
339 \\
323\end{array}$ & $\begin{array}{r}\text { ml. at } N . T . P . \\
\text { per min. } \\
315 \\
306\end{array}$ & $\begin{array}{l}24 \\
17\end{array}$ & $\begin{array}{l}\text { B before } A \\
\text { A before } B\end{array}$ \\
\hline I. G. & $\begin{array}{l}292 \\
288\end{array}$ & $\begin{array}{l}268 \\
264\end{array}$ & $\begin{array}{l}24 \\
24\end{array}$ & $\begin{array}{l}\text { B before } \mathbf{A} \\
\mathbf{A} \text { before } \mathbf{B}\end{array}$ \\
\hline C. D. & 267 & 240 & -27 & A before $\mathbf{B}$ \\
\hline Mean & 302 & Mean 279 & Mean 23.2 & \\
\hline
\end{tabular}




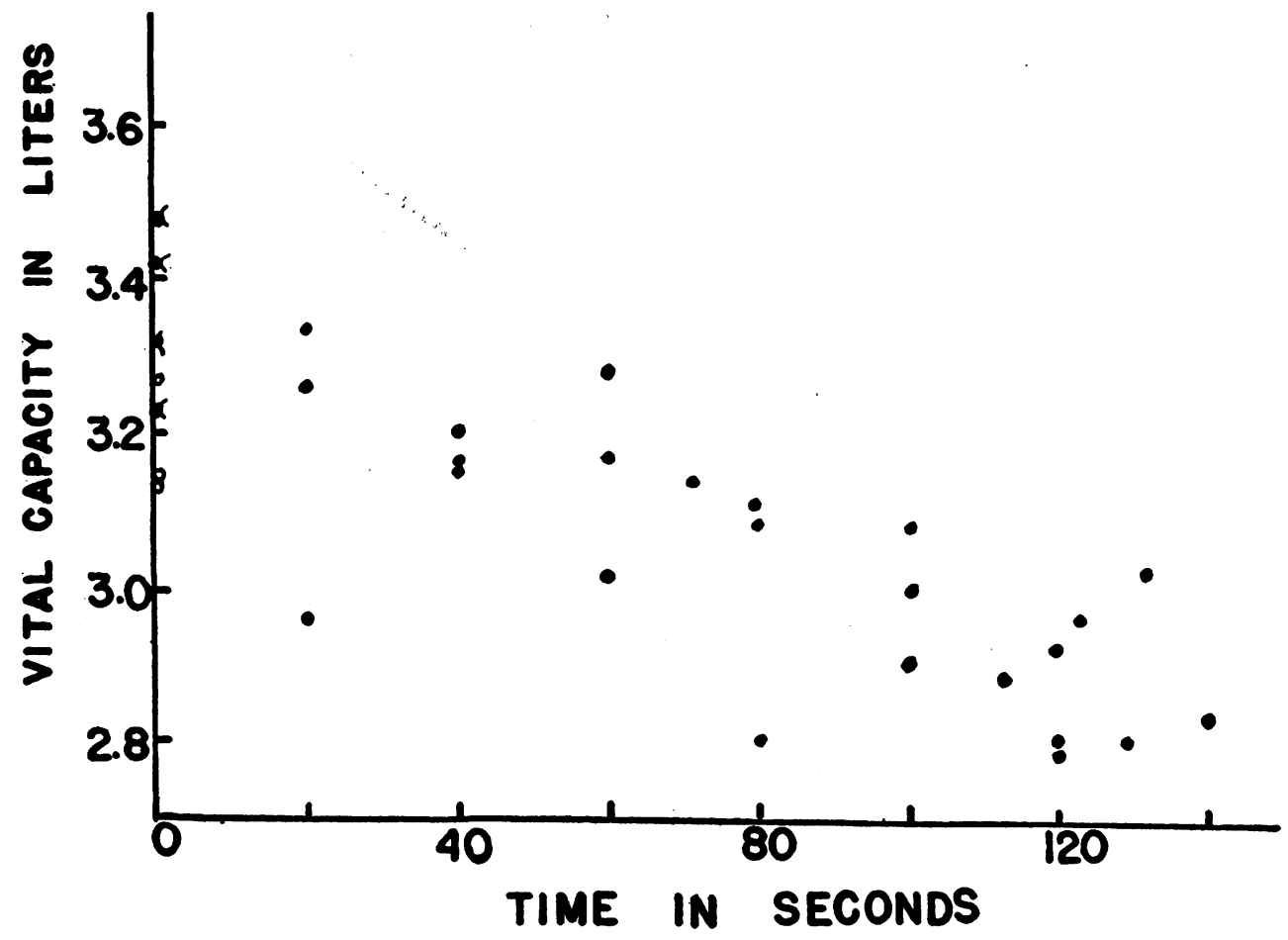

Fig. 2. The Effect of Varying Periods of Breathholding Upon the Vital Capacity (Maximum Expiratory Capacity)

Breathholding preceded by breathing of 100 per cent oxygen.

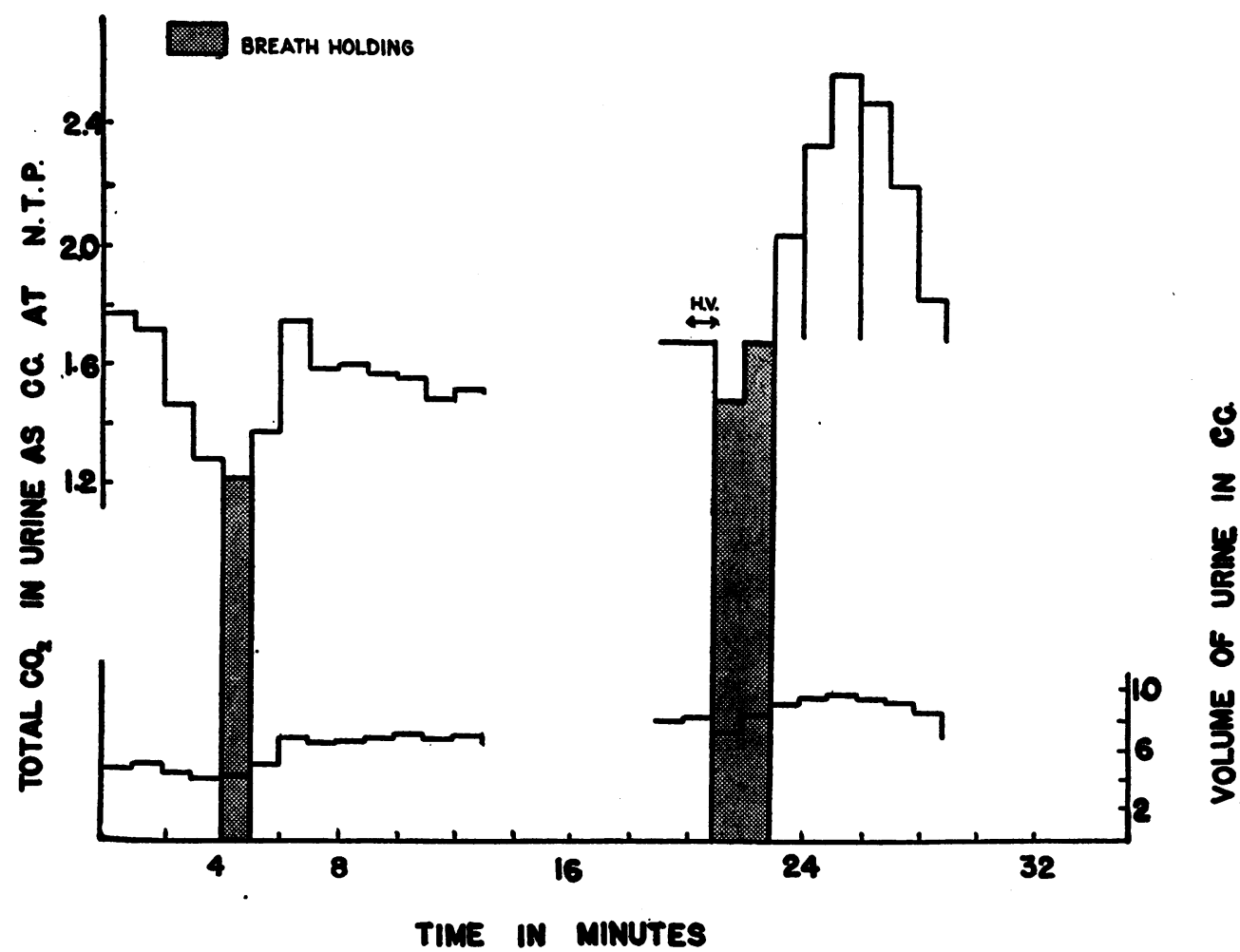

Fig. 3. Excretion of $\mathrm{CO}_{2}$ and Water by the Kidneys During Breathholding "H.V." indicates a period of hyperventilation preceding breathholding. The shaded area represents the period of breathholding. 


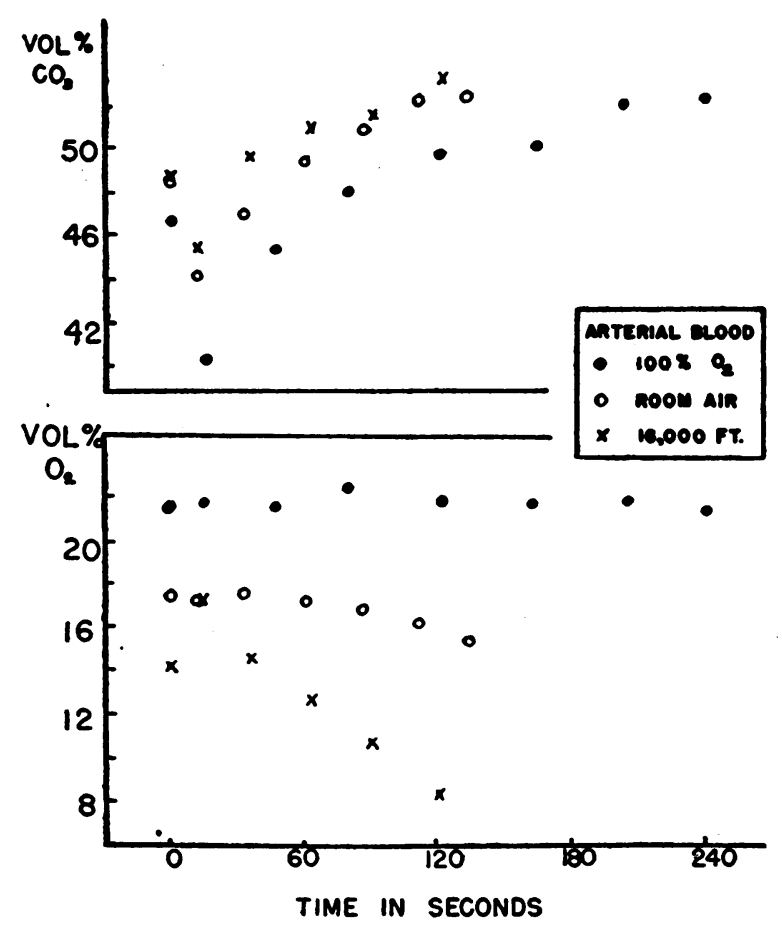

Fig. 4. Changes in the Blood Gases During Periods of Breath holding

These studies made immediately following the breathing of room air, 100 per cent oxygen, and ambient air at a simulated altitude of 16,000 feet.

culated from $\mathrm{CO}_{2}$ content and $\mathrm{pH}$ of arterial blood) during breathholding, which amounts to little more than 0.5 per cent by volume of $\mathrm{CO}_{2}$ per minute, one may also conclude that most of the $\mathrm{CO}_{2}$ being produced by the body remains in a combined state in the blood and tissues, and that very little passes into the lungs in the gaseous state.

The arterial oxygen content after inhalation of 100 per cent oxygen showed no significant change during periods of breathholding as long as 4 minutes. After inhalation of room air, the oxygen content of the arterial blood dropped appreciably during breathholding. And after inhalation of ambient air at 16,000 feet, the oxygen content of arterial blood decreased markedly during breathholding. This will be further exemplified and discussed in the third paper of this series.

\section{DISCUSSION}

It is clear, from the data presented above, that there is a marked decrease in the volume of gas in the lungs during breathholding, provided one has been breathing gas containing 21 to 100 per cent oxygen. It is also apparent that the rate at which this decrease in gas volume occurs, approximates the rate at which oxygen is absorbed from the lungs. Thus, the rate of oxygen uptake of the body as measured by the metabolism apparatus is only slightly greater than the rate of decrease in buoyancy under water following breathing of 100 per cent oxygen. Breathholding with 10 per cent oxygen is accompanied by a very slow rate of buoyancy change. This slow rate may be attributed to the failure of sufficient oxygen to move from the larger gas spaces in the lungs, which might be termed collectively the lung dead space, into the alveoli and the arterial blood. This failure is also demonstrated by the slight decrease in oxygen content of the arterial blood during breathholding with air at ground level, as compared to the marked decrease at a stimulated altitude of 16,000 feet.

The decrease in pulmonary oxygen volume during breathholding is partially counteracted by a slow addition of $\mathrm{CO}_{2}$ to the gas phase. The results of Hill and Flack (2) demonstrated that increase in alveolar $\mathrm{CO}_{2}$ is not great during breathholding, their data indicating that 7 to 8 per cent $\mathrm{CO}_{2}$ by volume might represent the maximum concentration one might expect to find in the alveoli at the end of breathholding following 100 per cent oxygen inhalation. The arterial $\mathrm{CO}_{2}$ reached in our studies indicate alveolar levels of approximately these percentages, which would give only a small increase in gas volume compared to the decrease due to oxygen absorption. The rate of $\mathrm{CO}_{2}$ accumulation in the arterial blood during breathholding did not vary at the different oxygen tensions $\left(\mathrm{pO}_{2}\right)$ we employed. The reason the $\mathrm{CO}_{2}$ fails to enter the gas phase in the lungs in greater amounts, is that most of it remains dissolved in the blood and tissues.

\section{SUMMARY AND CONCLUSIONS}

1. During underwater breathholding, the buoyancy of an individual as determined by changes in underwater weight decreases progressively. It has been demonstrated that this loss of buoyancy is due to a diminution in lung volume which occurs during breathholding. The decrease in lung volume occurs because oxygen diffuses out of 
the lungs much faster than $\mathrm{CO}_{2}$ diffuses in, most of the $\mathrm{CO}_{2}$ being retained by solution in the blood and tissue fluid during breathholding.

2. The rate of change in lung volume is dependent upon the $\mathrm{pO}_{2}$ of the initially inspired air, in that the higher the $\mathrm{pO}_{2}$, the greater is the rate of loss of lung volume (chiefly oxygen). After inhalation of 100 per cent oxygen, the rate of change in lung volume is only slightly less than the oxygen consumption of the body.
We are indebted to Jane K. Friedlander for her technical assistance.

\section{BIBLIOGRAPHY}

1. Behnke, A. R., Jr., Feen, B. G., and Welham, W. C., The specific gravity of healthy men. J. A. M. A., 1942, 118, 495.

2. Hill, L., and Flack, M., The influence of oxygen inhalations on muscular work. 1910, 40, 347. 